\title{
Solving the Puzzle of Relative Importance of Dividends and Retained Earnings in Stock Valuation: A Case of Karachi Stock Exchange
}

\author{
Asma Tariq1, Mina Kharal2, Muhammad Abrar ${ }^{3 *}$, Alishba Ahkam², \\ Muhammad Sarfraz Khan' \\ ${ }^{1}$ Heritage International College, University of South Asia, Lahore, Pakistan \\ ${ }^{2}$ Department of Business Administration, Faculty of Management Sciences, National Textile University, \\ Faisalabad, Pakistan \\ ${ }^{3}$ Department of Business Administration, Faculty of Management Sciences, National Textile University, \\ Faisalabad, Pakistan \\ Email: ${ }^{*}$ abrarphd@gmail.com
}

Received 3 August 2014; revised 6 September 2014; accepted 4 October 2014

Copyright (C) 2014 by authors and Scientific Research Publishing Inc.

This work is licensed under the Creative Commons Attribution International License (CC BY).

http://creativecommons.org/licenses/by/4.0/

(c) (i) Open Access

\begin{abstract}
Despite the growing debate on the stock price valuation, it has become a complex puzzle. Various theories, models and explanations have been provided to solve this confusing riddle. This study contributes to this debate by determining the relative importance of stock dividends and retained earnings regarding stock price valuation in Karachi Stock Exchange. Data for the analysis of this study were collected from the 66 nonfinancial companies that were included in KSE-100 index for a period from 2007 to 2010 . This study found the evidence that dividends are more important variable than the retained earning regarding the explanatory power of stock prices in Karachi Stock Exchange. Practical implications are also provided in the study.
\end{abstract}

\section{Keywords}

Dividends, Retained Earnings, Stock Valuation, Karachi Stock Exchange

\section{Introduction}

The active debate on the stock prices was started after the publication of the work of John Burr Willams in 1938, who for the very first time proposed about stock prices and the function of the dividends instead of the profits of

*Corresponding author.

How to cite this paper: Tariq, A., et al. (2014) Solving the Puzzle of Relative Importance of Dividends and Retained Earnings in Stock Valuation: A Case of Karachi Stock Exchange. Theoretical Economics Letters, 4, 681-690.

http://dx.doi.org/10.4236/tel.2014.48086 
the firm as it was believed at that time (Williams [1]). The foundations laid by Williams were explored by the early researchers. Some conformed the explorations of the Williams (Walter [2], Lintner [3], Friend \& Puckett [4]), while others (see, Miller \& Modigliani [5]) provided different views. The debate on the topic is still open despite the availability of so much literature and wide variety of models. Scholars and practitioners could not develop a precise model to predict the accurate movements of the stock price in the stock exchanges. So far dividends have yet been considered to be the most important determinant of the stock price (Khan [6]).

After the work of the Williams [1], Miller \& Modigliani [5] proposed their dividend irrelevance theorem, which states that firm value is not dependent upon its dividend policy rather on its earning ability. But Jensen \& Meckling [7] provided that dividends might matter to the investors in agency cost considerations. They advocated that dividends bring managerial efficiency and discipline within the organization, so investor might prefer higher dividend-paying firm. Moreover, dividends are said to provide a signaling mechanism to the outside word regarding the future prospects of the organization (Miller \& Rock [8]). Higher dividends signal good future performance and vice versa. This signaling mechanism works due to information asymmetry problem which is prevalent in the market due to the fact that managers operating the organization have better information regarding the current performance and future prospects of the organization than those who invest in a corporation. So if the mangers are confident about the future of the company, they would distribute more cash to the investors in the shape of dividends and if they are not much confident would like to retain the cash for contingencies. Another reason for the preference of the investor to the dividend-paying firms might be the clientele effect (Miller \& Modigliani [5]) that advocates that investors have different preferences regarding the dividend policies, so a particular firm tend to attract a particular clientele of investor and changing dividend policy may cause the investor to switch toward a more proffered security suitable to the preference of that investor.

Retained earnings on the other hand are the profits of the organization that are reinvested in the business. According to Pardhan [9] high retained earning implies that firm is in growth phrase and has good future prospects. From this point of view we cannot deny the importance of retained earnings. Some studies found a strong impact of the retained earnings on the stock price such like Havkevy [10] who provided such evidence in case that retained earnings should accompany increase in the profitability of the firm. Walter [2] also provided that in case of growth firms the higher retained earnings and lower dividends increase the value of the firm. Miller \& Modigliani [5] on the other hand suggested that the magnitude of retained earnings and dividends do not affect the value of the firm. The theories and proposition in this regard are too complex and difficult to be selected. The aim of this study is to solve this puzzle by fining the relative importance of dividends and retained earnings in determining the stock prices of nonfinancial sector of Karachi Stock Exchange. This study would provide the empirical evidence regarding the subject and enable the investors and practitioners to grasp the phenomenon in the true sense.

\section{Literature Review}

This literature review summarizes some important research studies relating to the valuation of stocks, considering dividends and retained earnings. Literature review provides a bird's eye view regarding past developments and findings relating to the topic.

Havkevy [10] was one of the founders of the security analysis who investigated the relationship between common stock price and retained earnings for listed corporations. Using the data of Cowles All Stock Index from 1871 to 1937 and from Standard and Poor's Industrial, Rails and Composite Index from 1934 to 1950, he found a significant correlation between price earnings ratio and dividend, implying that the price of the stock would be higher which paid larger dividends as compared to a similar stock paying lesser dividend. This study also found a correlation of price earning with retained earnings indicating that higher earning retained would cause price appreciation of the stocks but these higher retained earnings should accompany increase in profitability of the corporation as indicated by the case studies provided in this empirical work.

Walter [2] also argued that stock prices are dependent upon the future dividends but in case of growth stocks low dividend payout or higher earning retentions enhance the value of the organization. Moreover, preferred tax rates on capital gains also implied that the capitalization of the organization increases with retained earnings. Apart from that for most of the large corporations have the investment opportunities with a rate of return more than zero but less than the prevailing market capitalization rates that condition tend to favor larger dividend payout regarding the value of the organization. 
The most cited work in this regard is of Lintner [3] who conducted the field research to grasp the phenomenon of dividend policy and its impact on organization value by mean of selecting 28 corporations for detailed investigation of financial affairs from 1947 to 1953 and subsequent interviews from the key figures of selected corporations. The research indicated that management of the corporations showed reluctance to alter the established dividend policies due to fear of adverse response of such change from stock holder's side.

A significant development on the determination of share price was done by David Durand [11]. He sought to determine the factors that affected the market to book value ratio of the banks as this ratio was considered important with regard to fund raising through stock issue. The study considered earning to book value, dividend rate, and size of the bank as independent variables and data was collected from five groups of bank stocks along with New York bank stocks for eight years period of 1946-1953. The results indicated that dividend payout was not that important determinant of stock price of New York bank stocks, although it strongly influenced on bank stocks of other groups. Moreover, only the variables of dividends and earnings provided indication of the systematic influence over the bank stock price to book value.

Gordon [12] also provided one of the seminal evidence with regard to predictability of stock price. He used the two years (1951 and 1954) data relating to four industries (Chemical, Food, Steel and Machine tools) for the variables of stock price, earning and dividends. Three prepositions are tested in this study that stock prices are determined by both dividends and earnings, alone by dividends and alone by earnings. They provided that the model for first preposition is conceptually weak, but provides significant results most of the time with regard to predictability power of dividends and earnings. The second model used retained earnings as proxy of growth in dividends along with dividends as independent variables. The results provided that when growth of the firm is valued over the dividends, the increase in dividends on the cost of decrease in retained earnings do not increase the value of the firm and vice versa. Moreover, the price could be predicted through this model more accurately when the retained earnings are held constant. They also proposed that dividend model outperforms all other models with regard to predictability power and significance. They also proposed to include variables of average dividend and average retained earnings both for last five years to include the impact of past trend in the regression.

Miller and Modigliani [5] on the other hand, by mean of theoretical evidence proposed that firm's value is not determined by the dividend policy of the firm but by the earning ability of the firm and its investment policy, which are the real considerations in this for stock valuation. They criticized on Gordon dividend discount model by saying that the excessive payments of dividends would limit the funds needed to finance new projects and thus would affect the size of the future dividends or risk attached to these dividends in case firm opt for external financing of debt. This paper favors the dividend irrelevance theorem even in the absence of certainty and in market imperfections.

In response to the criticism of the MM, Gordon [13] provided further argument on his theory of stock valuation by mean of dividend policy. They proposed that under the conditions of uncertainty a Dollar paid today would be more valued than a one Dollar increase in share price in some distant future and most of the investors are risk averse in nature so they would be willing to pay the premium to minimize the future uncertainty with regard to stock price. They theoretically concluded that stock price could not be deemed as irrelevant to the dividend policy.

Lintner [14] on the other hand, investigated the phenomenon of impact of financing mix and dividend policy on the value of corporation, by means of theoretical justifications. He concluded that valuation of unlevered equity is not determined by the dividend in absence of uncertainty only so the notion that share prices are determined by the discounting the future values of the dividends hold to the truth in the generalized circumstances. Apart from that, under the certain conditions the alternatives of cash dividends, retained earnings and new debt yield the indifferent results but when the uncertainty, cost of financing and taxes are taken into account the investor would determine the price of the security on the basis of generated cash flows i.e. cash dividends. Moreover, the financing mix also effects the equity valuation of the company and the stock value would not always be equal to the total entity value minus debt value when the financing mix changes, except in the condition of certainty.

Friend \& Puckett [4] discussed the relative importance of the retained earnings and dividend payout ratio in determination of price earnings ratios of the stocks. They also highlighted the modeling discrepancies with regard to the phenomenon. Using the cross sectional data of five industries i.e. electronics, foods, steels, chemicals and electric utilities for two years, 1956 and 1958 they provided empirical evidence with regard to traditional 
model and model suggested by them. For traditional model they found a relatively strong positive impact of dividend payout on the stock price in comparison to the impact of retained earnings in tree industries out of total five i.e. foods, steel and chemicals. The results with regard to the strength of impact were vice versa for the reaming two industries i.e. electronics and electrical utilities. To hold the firm effect constant they included the variable of lagged earning price ratio in the regression and found almost same results except that the strength of dividends in relation to retained earnings in predicting stock prices declined a bit. To minimize the bias of short run price movements the lagged price variable was included in the regression which provided stronger effects of retained earnings then of dividend payout in three industries of chemical, electronics and utilities, while the effect difference as not that systematic for the remaining two industries of steel and foods. Other competing models are also employed in this research to minimize the potential bias in the traditional regression equation. This research on the whole indicates that investor consider dividend more while valuating the non growth firm and higher retained earnings is valued more for the growth industries.

Another study conducted by Pardhan [9] tried to establish the relationship between dividends, retained earnings and share price in the corporate settings of Nepal. Using pooled data of 29 companies for the period from 1991 to 1999 and running various linear and logarithmic form regressions with and without lagged variables of price earnings ratio and market price to assume firm's effect constant, they assessed the relative importance of dividends and retained earnings in determination of the stock price. The study confirmed the traditional relationship in which dividends are more important than retained earnings in predicting stock price in Nepalese corporate sector.

The research of Azhagaiah and Priya [15] also highlighted the importance of dividends in determination of stockholder's wealth for chemical industry (both organic and inorganic) of India using the data for years 19972006. By comparing the means of firms paying dividends and those not paying dividends, they concluded that the means of market to book value for dividend paying companies are significantly higher than those companies not paying the dividends. Moreover, to establish the relationship between stock prices and other independent variables i.e. dividend per share, retained earning divided by numbers of outstanding shares, lagged price/earnings ratio and lagged market price of share. They concluded that all the independent variables used in the study are significant predictors of the share price for inorganic chemical organizations, while dividend per share was significant and positive for organic and all chemical companies as well and variable of lagged market price of share was significant in regression run for all companies as in inorganic chemical organization.

Khan [16] provided empirical evidence with regard to the relative impact of dividends and retained earnings on the stock price of companies listed in Dhaka Stock Exchange. Apart from dividends and retained earnings, certain other control variables such as lagged price earnings ratio and previous year's price are also regressed against the stock price of the listed companies. Data was collected for the period of 2000-2006. Using different model comprising the variables provided before they concluded that dividends, retained earnings and remaining variable have dynamic relationship with the price of the company. Dividend was found to be the most important determinant of stock price in Bangladesh while retained earnings, were deemed second.

\section{Methodology}

This part explains the methodology of the research by specifying the model of the research and by describing the sample used in this study.

\subsection{Model Specification}

This section specifies the model relating to the determination of the relative importance of dividends and retained earnings in explanation of the stock prices. As the proposition entails that present value of the future cash flows should be the base of determination of the stock price so cash flows are dividends and the liquidation cash flow at some time in the future. This liquidation cash flow is composed of the value of the assets of the company with is financed by the debts and equity along with retained earnings. Retained earnings on the other hand could be a measure of the growth of the firm as greater retained earnings entail that firma has greater need of financing and thus growing. Relative importance of the retained earnings and dividends has been a matter of interest since the beginning. We follow the methodology of Friend \& Pukett [4]. This methodology was also replicated by Kumar \& Mohan [17], Pardhan [9], Azhagaiah \& Priya [15] and Khan (2009). There is an evidence of this type of empirical investigation in Pakistan as well (Nishat, [18]). The basic model to measure the relative importance 
of the dividend and retained earnings is specified as follows:

$$
\mathrm{MP}_{i t}=\beta_{0}+\beta_{1} \mathrm{DPS}_{i t}+\beta_{2} \mathrm{RE}_{i t}+\mathrm{e}_{i t}
$$

where

$\mathrm{MP}_{i t}=$ Market price of the stock of the firm $i$ at time $t$;

DPS $_{i t}=$ Dividend per share of the firm $i$ at time $t$;

$\mathrm{RE}_{i t}=$ Retained earnings per share of the firm $i$ at time $t$;

$\mathrm{e}_{i t}=$ Error term.

The above regression model however is said to be prone to bias of two types (Khan [16]). First, this model assumes that risk is held constant by choosing the sample from a particular industry only and dividend payout and risk are uncorrelated and second that the retained earnings solely determine the growth potential of the firm. This problem could be dealt with adding a lagged variable of price earnings ratio in the model as companies of different size, product mix and financial structure should have different risk and higher risk implies that companies should adopt a lower dividend payout policy in a view to deal with future adverse variations in the earnings that might force the firms to cut the dividends, thus high risk would imply both lower payout and lower price earnings ratio and vice versa (Friend and Pukett [4]). Pardhan [9] also proposed that firm effects such like discussed before should be held constant by introducing variable of lagged price earnings ratio as this ratio is an accurate measure of investor assessment of risk and profit prospect arising out of investment opportunity being financed either through internal investment i.e. retained earnings or external debt or equity financing. So after inclusion of said variable, we would arrive at the following model:

$$
\mathrm{MP}_{i t}=\beta_{0}+\beta_{1} \mathrm{DPS}_{i t}+\beta_{2} \mathrm{RE}_{i t}+\beta_{3} \mathrm{PE}_{i(t-1)}+\mathrm{e}_{i t}
$$

where $\mathrm{PE}_{i(t-1)}=$ Price earnings ratio of firm $i$ at time $t-1$ (previous year).

The other bias in the Equation (I) is that the reported income of the firms is a faction of several accounting and short run economic factors. The accounting procedure requires the corporations to estimate the earning of the corporations conservatively; the principle of conservatism. This gives rise to bias in the reported earnings. The dividend amount on the other hand is measured precisely and the impact of this measurement error is born by the retained earnings. This effect in this way could produce a downward bias towards the retained earnings (Friend and Pukett [4]). Short run changes in income on the other hand, evoke relatively small fluctuation in the respective price (see, Pardhan [9]) so this problem could be solved by adding lag of market price into the equation. So the model equation would be:

$$
\mathrm{MP}_{i t}=\beta_{0}+\beta_{1} \mathrm{DPS}_{i t}+\beta_{2} \mathrm{RE}_{i t}+\beta_{3} \mathrm{MP}_{i(t-1)}+\mathrm{e}_{i t}
$$

where $\mathrm{MP}_{i(t-1)}=$ Market Price of the stock of the firm $i$ at time $t-1$ (previous year).

This is consistent with the price behavior as in Equation (III) price of the company is determined by the previous expectations on the current expectations of the price, dividends and retained earnings (Friend and Pukett [4], Pardhan [9], Khan [16]).

\subsection{Sample}

For the empirical investigation a sample of 100 companies, which constitute KSE-100 index at Karachi Stock Exchange was selected. KSE-100 index is most widely used measure of stock market activity in Pakistan. The companies contained in the index are selected by their market capitalization and to assure the adequate representation of every industry sector, companies from each sector having highest market capitalization within the sector are also included in this index. By all means KSE-100 is considered an appropriate measure to represent all the variations in the overall prices of stock market in Pakistan. While all the industrial sectors are reflected in this index the companies included in the index could broadly be categorized in two type i.e. financial companies and non-financial companies. KSE-100 index is composed of 24 financial companies and 76 non-financial companies. Financial companies were excluded for the analysis because of their different type of nature. Data for the four other nonfinancial companies were also not available so they were also excluded from the analysis. A further six companies were also not included in the final sample due to the fact that they were not dividend paying firms and as the research is about the relative importance of dividends and retained earnings in deter- 
mining the stock prices so companies with zero dividend for all time spam of the study could mislead the results. So, final sample constitutes 66 nonfinancial firms in total. The sample constitute all the significant firms representing non-financial sector which pay dividends making the results of the study generalizable to the whole nonfinancial sector of Karachi Stock Exchange.

Data were collected from the analysis reports provided by the Karachi Stock Exchange on their website and from state bank publication namely "Balance Sheet Analysis of the Joint Stock Companies Listed in Karachi Stock Exchange” Issue (2003-2008) and (2004-2009). This study covers a time spam of four years from 2007 to 2010. Data was pooled for the analysis and OLS regression technique is used to draw inferences from the study.

\section{Analysis}

This part of the study provides descriptive, correlation and regression analysis for this study.

\subsection{Descriptive Statistics}

Table 1 provides the descriptive statistics for Models I, II and III. Market price (MP) being the dependent variable and all other being the independent variables i.e. dividend per share (DPS), retained earnings per share (RE), lag value of price earnings ratio $\left(\mathrm{PE}_{(t-1)}\right)$ and lag of market price $\left(\mathrm{MP}_{(t-1)}\right)$. Model I as previously specified only considers dividend per share and retained earnings per share as independent variables, while Model II considers lag of price earnings ratio along with dividend per share and retained earnings per share and Model III considers lag of market price along with the variables included in Model I. The mean value of the dependent variable i.e. MP is 319.26 along with a median of 138.46 and standard deviation of 568.91. The minimum market price in the whole of the data set was 4.89 and maximum market price was 4448 . The overall, data set comprises companies with varying market price and characteristics making the analysis to be more generalizable. The first independent variable of the study is dividend per share (DPS) which had mean and median of 15.85 and 6 respectively along with a standard deviation of 29. The minimum and maximum of the variable were 0.5 and 299 respectively. The second independent variable of the study is retained earning which had mean and median of 15.85 and 5.88 respectively. The standard deviation for RE variable was 27.83 and minimum and maximum values are -56.54 and 27.83 respectively. The next variable inline is lag of price earning of the firm which had mean value of 7.13 and median of 10.55 . The standard deviation for the variable is 51.72 along with minimum of -609.34 and maximum of 111.73 . The last variable is lag of market price which had mean of 321.44 along with the median of 174.25. The standard deviation of the variable was 543.32 and minimum along with the maximum values were 3.55 and 4448 respectively. The overall data set indicates much variability which implies that the results of the study would be more generalizable.

\subsection{Correlation}

Table 2 following correlation analysis for the variables used the analysis of this study. The primary purpose of this correlation analysis is to diagnose any trace of multicollinearity. For this purpose we have opted for a cut off value of 0.8 as a measure of high correlation among the independent variables as suggested by Gujarati and Sangeetha [19]. Moreover, correlation analysis could also be used as initial investigation into the direction of the relationship between dependent and independent variables.

No value of Pearson correlation coefficient increases the cut off value of 0.8 for all variables used in this study. So we may say that there is no high correlation among the independent variables used in the study. The highest correlation coefficient among independent variables is around 0.7 indicating a moderate correlation between lag of market price and dividend per share the reason for this correlation might be the fact that the prices of a security reflect the future dividends as well. This is a realistic situation so this correlation could be ignored for the purpose of the analysis.

Moreover, according to Table 3 (regression analysis), the relationship of dependent variable i.e. market price with main independent variables i.e. dividends and retained earnings is found positive and there is a clear indication that dividends have a stronger correlation with stock price than retained earnings as provided by correlation coefficient value. The relationship of dividend per share, retained earnings and lag of market price was found significant while the correlation between lag of price earning and market price was deemed insignificant. 
Table 1. Descriptive statistics (Models I, II and III).

\begin{tabular}{|c|c|c|c|c|c|}
\hline & MP & DPS & $\mathrm{RE}$ & $P E_{(t-1)}$ & $\mathrm{MP}_{(t-1)}$ \\
\hline Mean & 319.2625 & 15.84937 & 13.3681 & 7.13127 & 321.4357 \\
\hline Median & 138.46 & 5.99969 & 5.874912 & 10.54747 & 174.25 \\
\hline Maximum & 4448 & 229.0095 & 210.8868 & 111.7307 & 4448 \\
\hline Minimum & 4.89 & 0.499966 & -56.53852 & -609.34 & 3.55 \\
\hline Std. Dev. & 568.9087 & 28.99948 & 27.83083 & 51.72203 & 543.3233 \\
\hline Skewness & 3.92404 & 3.958715 & 3.010484 & -10.57026 & 4.263973 \\
\hline Kurtosis & 22.34909 & 22.89993 & 19.55701 & 126.4271 & 26.08894 \\
\hline Jarque-Bera & 2942.862 & 3096.178 & 2095.109 & 105847.9 & 4089.318 \\
\hline Probability & 0 & 0 & 0 & 0 & 0 \\
\hline Sum & 51720.53 & 2567.598 & 2165.632 & 1155.266 & 52072.58 \\
\hline Sum Sq. Dev. & 52108802 & 135396.2 & 124703.3 & 430702.1 & 47527226 \\
\hline Observations & 162 & 162 & 162 & 162 & 162 \\
\hline
\end{tabular}

Table 2. Correlation analysis (Models I, II and III).

\begin{tabular}{|c|c|c|c|c|c|}
\hline & & DPS & $\mathrm{RE}$ & $\mathrm{MP}_{(t-1)}$ & $\mathrm{PE}_{(t-1)}$ \\
\hline \multirow[t]{2}{*}{ MP } & Pearson Correlation & $0.6867^{* *}$ & $0.3303^{* *}$ & $0.74121^{* *}$ & 0.0631 \\
\hline & Sig. (2-Tailed) & 0.0000 & 0.0000 & 0.0000 & 0.4248 \\
\hline \multirow[t]{2}{*}{ DPS } & Pearson C & & $0.2419^{* *}$ & $0.7009^{* *}$ & 0.0808 \\
\hline & Sig. (2-Tailed) & & 0.0019 & 0.0000 & 0.3067 \\
\hline \multirow[t]{2}{*}{$\mathrm{RE}$} & Pearson $\mathrm{C}$ & & & $0.2387^{* *}$ & 0.0115 \\
\hline & Sig. (2-Tailed) & & & 0.0022 & 0.8841 \\
\hline \multirow[t]{2}{*}{$\mathrm{MP}_{(t-1)}$} & Pearson C & & & & 0.1513 \\
\hline & Sig. (2-Tailed) & & & & 0.0545 \\
\hline
\end{tabular}

** Correlation is significant at the 0.01 level (2-tailed).

\subsection{Regression Analysis}

Model I established the primary relationship between the primary independent variables of dividend per share and retained earnings. This model is good fit as indicated by the F-statistic of 79.5689. This model predicts almost $50 \%$ variation in the stock price as the value of adjusted $\mathrm{R}$ square is 49.393 . Durbin-Watson test value, on the other hand was found to be 2.034496 for the Model I, which indicates that no serial correlation exists in Model I as the test values are near the standard of 2. Model II on the other hand considers lag of price earnings ratio along with the main variables under consideration i.e. dividend per share and retained earnings per share to control for firm characteristics which are directly immeasurable otherwise. The usefulness of this inclusion would be judged by the relative increase in the goodness of fit of the model as indicated by the F-statistic and increase in the value of adjusted R square in comparison to the value in Model I. The inclusion of this variable has led to a decrease in the value of F-statistics to 52.7927 a value of 79.5689 in Model I. There is also no indication of improvement in the values of adjusted $\mathrm{R}$ square and a slight decrease in its value is also noted. The values of adjusted R square in the Model I was 0.49393 while its values in Model II is found 0.490811 . The Durbin-Watson stat does not find trace of multicollinearity as calculated value i.e. 2.034608 is quite near to the standard of 2. While, Model III considers variable of lagged market price as a measure of the previous expectations to current expectations of the company prospects along with the main variables i.e. dividend per share and retained earnings per share. The significance of this variable inclusion is measured by increase in the F-statistic which is a measure of overall goodness of fit of model and increase in the value of adjusted R square which is a measure of predictability power of the model, from the value provided by Model I. The inclusion of this variable has significantly increased the F-statistics from 52.7927 to 86.7209 . The adjusted R square has also shown improvements and has grown from to 0.614982 . A slight trace of positive autocorrelation in the Model III is found 
Table 3. Regression analysis.

\begin{tabular}{|c|c|c|c|c|}
\hline \multicolumn{5}{|c|}{ Regression Analysis (Model I: $\mathrm{MP}_{i t}=\beta_{0}+\beta_{1} \mathrm{DPS}_{i t}+\beta_{2} \mathrm{RE}_{i t}+\mathrm{e}_{i t}$ ) } \\
\hline Variable & Coefficient & Std. Error & t-Statistic & Prob. \\
\hline C & 71.20066 & 38.02481 & 1.87248 & 0.063 \\
\hline DPS & 12.64378 & 1.133567 & 11.154 & 0 \\
\hline $\mathrm{RE}$ & 3.565653 & 1.181167 & 3.01875 & 0.003 \\
\hline R-Squared & 0.500217 & Mean Dependent Var & & 319.263 \\
\hline Adjusted R-Squared & 0.49393 & S.D. Dependent Var & & 568.909 \\
\hline S.E. of Regression & 404.7137 & Akaike info Criterion & & 14.8626 \\
\hline Sum Squared Resid & 26043112 & Schwarz Criterion & & 14.9198 \\
\hline Log Likelihood & -1200.869 & F-Statistic & & 79.5689 \\
\hline Durbin-Watson Stat & 2.034496 & Prob(F-Statistic) & & 0 \\
\hline \multicolumn{5}{|c|}{ Regression Analysis (Model II: $\mathrm{MP}_{i t}=\beta_{0}+\beta_{1} \mathrm{DPS}_{i t}+\beta_{2} \mathrm{RE}_{i t}+\mathrm{PE}_{i(t-1)}+\mathrm{e}_{i t}$ ) } \\
\hline Variable & Coefficient & Std. Error & t-Statistic & Prob. \\
\hline C & 70.69989 & 38.26786 & 1.8475 & 0.0665 \\
\hline DPS & 12.62898 & 1.140748 & 11.0708 & 0 \\
\hline $\mathrm{RE}$ & 3.567237 & 1.184842 & 3.01073 & 0.003 \\
\hline$P E_{i(t-1)}$ & 0.100145 & 0.620627 & 0.16136 & 0.872 \\
\hline R-Squared & 0.500299 & Mean Dependent Var & & 319.263 \\
\hline Adjusted R-Squared & 0.490811 & S.D. Dependent Var & & 568.909 \\
\hline S.E. of Regression & 405.9589 & Akaike info Criterion & & 14.8748 \\
\hline Sum Squared Resid & 26038821 & Schwarz Criterion & & 14.951 \\
\hline Log Likelihood & -1200.856 & F-Statistic & & 52.7297 \\
\hline Durbin-Watson Stat & 2.034608 & Prob(F-Statistic) & & 0 \\
\hline \multicolumn{5}{|c|}{ (Model III: $\mathrm{MP}_{i t}=\beta_{0}+\beta_{1} \mathrm{DPS}_{i t}+\beta_{2} \mathrm{RE}_{i t}+\mathrm{MP}_{i(t-1)}+\mathrm{e}_{i t}$ ) } \\
\hline Variable & Coefficient & Std. Error & t-Statistic & Prob. \\
\hline $\mathrm{C}$ & 19.98011 & 33.93348 & 0.5888 & 0.5568 \\
\hline DPS & 6.048764 & 1.352993 & 4.47065 & 0 \\
\hline $\mathrm{RE}$ & 2.827333 & 1.035434 & 2.73058 & 0.007 \\
\hline $\mathrm{MP}_{(t-1)}$ & 0.515242 & 0.072155 & 7.14078 & 0 \\
\hline R-Squared & 0.622157 & Mean Dependent Var & & 319.263 \\
\hline Adjusted R-Squared & 0.614982 & S.D. Dependent Var & & 568.909 \\
\hline S.E. of Regression & 353.0067 & Akaike info Criterion & & 14.5952 \\
\hline Sum Squared Resid & 19688971 & Schwarz Criterion & & 14.6715 \\
\hline Log Likelihood & -1178.214 & F-Statistic & & 86.7209 \\
\hline Durbin-Watson Stat & 1.968415 & Prob(F-Statistic) & & 0 \\
\hline
\end{tabular}

but this autocorrelation is easily negligible as provided by Durbin-Watson stat of 1.968415 , which are considerably near the standard of 2 .

Turing towards the key point which is the determination of the relative importance of the dividends and retained earnings in prediction of the stock price, which would be determined by the relative higher coefficient value and t-statistic, we found that dividend has more influence over the stock price than retained earnings in all three Models. For the Model I, variables of dividend per share and retained earnings per share have positive coefficients with values of 12.64378 and 3.565653 respectively along with t-statistics of 11.154 and 3.01675 respectively, clearly indicating that dividends have more explanatory power with regard to the determination of the share price for the entire sample used in this study. The results with regard to magnitude and direction of the 
relationship between dividends, retained earnings and stock price are almost the same for Model II as were in Model I. Dividends again conform to be more important determinant of the stock price than retained earnings as provided by greater regression coefficient of 12.62898 for dividends as compared to coefficient value 3.567237 for retained earnings. The t-statistics were also found higher for the dividend per share 11.0708 as compared to its value for the variable of retained earnings per share i.e. 3.01073 respectively. The relationship of retained dividend per share and retained earnings per share with stock price was found positive for all three data sets. The lagged price earnings ratio variable on the other hand, was found insignificant in regression run for Model II with t-statics 0.16136 . The direction of the relationship however, was found positive. This variable on the whole does not promise to have any significant change with regard to its impact on the estimation of relative importance of dividends and retained earnings. The question of relative importance of dividends and retained earnings still favors the dividends even after the inclusion of the lagged market price as control variable in Model III. The largest coefficient value of 6.048764 among all three variables and the second largest t-statistic value of 4.47065 strengthen the view that dividends probably are the most important factor that determines the stock prices in the stock markets. The variable of retained earnings per share provides a coefficient of 2.827333 along with a t-statistic of 2.37058 favoring the strength of dividends over retained earnings. The most significant variable in regression of Model III found to be lagged market price variable with the largest t-statistic of 7.14078 among all three variables used in this regression regression but a relatively smaller coefficient value i.e. 0.515242 . All the variables in Model III indicated a direct relationship with stock price.

This section probed into the question of relative importance of dividend and retained earnings by applying three models. A total of 3 regressions were run and the results overall supported the hypothesis that dividends have a positive impact on the stock prices so, hypothesis $\mathrm{H}_{\mathrm{a} 1}$ is accepted, the association of the retained earnings on the other hand also provided a positive impact on the stock prices so, $\mathrm{H}_{\mathrm{a} 2}$ is also accepted. Moreover, the results overall support the notion that dividends are more important than the retained earnings in determination of the stock prices, this leads towards the acceptance of hypothesis $\mathrm{H}_{\mathrm{a} 3}$ as Well. Apart from that, inclusion of the measure of the firm characteristics i.e. lagged price earnings ratio in the model as independent variable do not improve the estimation while inclusion of the lagged market price improves the estimation by increasing explained variance and overall goodness of fit of model.

\section{Conclusions}

The aim of this study was to seek out the question of relative importance of dividends and retained earnings in determination of stock price. A positive relationship of dividends and retained earnings was found for stock prices which are consistent with the literature on the topic. Dividend seems to be the most important variables with regard to the determination of stock prices in the stock market. Dividend is said to play a signaling mechanism for the investor to evaluate future prospects of the corporation thus reducing the information asymmetry problem. Theoretically, as proposed by Miller \& Modigliani [5] the decision regarding reinvestment of the profits into the business or paying it to the stock holders should not affect the value of the firm. But, evidence suggests that dividends are more important than retained earnings with regard to their impact on stock prices (Friend \& Puckett [4], Pardhan [9], Azhagaiah \& Priya [15]), so, dividends in this regard are said to have information content as to the correct valuation of the stock. This notion is also confirmed by the fact that dividend-paying firms on the average have higher stock prices than firms which do not pay the dividends (Nirmala, Sanju \& Ramachandran [20]).

Moreover, the inclusion of lag of price-earnings ratio variable in the basic regression model specifying market price as a function of dividends per share and retained earnings per share did not improve the estimation for our sample. The inclusion of lag of market price variables although brought some improvements in the model with regard to predictability power of model. On the whole this variable could be used to improve the estimation with regard to the relative importance of dividends and stock prices. This is also consistent with the previous finings (Friend \& Puckett [4], Pardhan [9]).

This research study not only bridges the gap in the existing literature with regard to stock price evaluation in one of the best performing market of the developing counties in the world but also provides valuable practical insights with regard to stock price movements in the Karachi Stock Exchange. Findings of the study would not only be beneficial for the policy makers in sense as to leverage economic growth by supporting the financial activities such as devising monetary and fiscal policy in a way to boost the trading activity in the stock market 
which in turn could contribute significantly towards the economic growth and also attract foreign direct investment into the country but also for the individual investors who can use the findings of this study to device his investment strategy. Moreover, the findings of this study are also beneficial for the managers of the corporate sector who strive hard to build the value of the firm with a view to providing maximum benefits to the shareholders.

This study also has certain limitations which should be considered necessary. First of all the scope of the study is only limited to the establishment of the relative importance of the dividends and retained earnings and it does not consider other implications of the dividend policy like information content of the dividends, tax differentials between dividends \& capital gains and agency cost implications of the dividends. These considerations clearly establish superiority of dividends over capital gains resulting from retained earnings. The empirical testing of these implications of the dividends is out of scope of this study and further research in the Pakistan would be more meaningful in this regard. Further, final sector is also excluded from the study due to distinct characteristics of financial sector and a subsequent study could also be conducted to test the relative importance of dividends and retained earnings for the financial sector and the findings of non-financial and financial sector could be compared for a better understanding of the dividends implications in both of the sectors.

\section{References}

[1] Williams, J.B. (1938) The Theory of Investment Value. Harvard University Press, Cambridge, MA.

[2] Walter, J.E. (1956) Dividend Policies and Common Stock Prices. The Journal of Finance, 11, 29-41. http://dx.doi.org/10.1111/j.1540-6261.1956.tb00684.x

[3] Lintner, J. (1956) Distribution of Incomes of Corporations among Dividends, Retained Earnings, and Taxes. The American Economic Review, 46, 97-113.

[4] Friend, I. and Puckett, M. (1964) Dividends and Stock Prices. The American Economic Review, 54, 656-682.

[5] Miller, M.H. and Modigliani, F. (1961) Dividend Policy, Growth, and the Valuation of Shares. The Journal of Business, 34, 411-433. http://dx.doi.org/10.1086/294442

[6] Khan, M.S. (2011) Stock Price Puzzle. Lambert Academic Publishing, Saarbrücken, Germany.

[7] Jensen, M.C. and Meckling, W.H. (1976) Theory of the Firm: Managerial Behaviour, Agency Costs and Ownership Structure. Journal of Financial Economics, 3, 305-360. http://dx.doi.org/10.1086/294442

[8] Miller, M.H. and Rock, K. (1985) Dividend Policy under Asymmetric Information. The Journal of Finance, 40, 10311051. http://dx.doi.org/10.1111/j.1540-6261.1985.tb02362.x

[9] Pardhan, R.S. (2003) Effects of Dividends on Common Stock Prices: The Nepalese Evidence. Research in Nepalese Finance, Buddha Academics, Kathmandu, 1-13.

[10] Harkavy, O. (1953) The Relation between Retained Earnings and Common Stock Prices for Large, Listed Corporations. The Journal of Finance, 8, 283-297.

[11] Durand, D. (1957) Bank Stock Prices and the Bank Capital Problem. National Bureau of Economic Research.

[12] Gordon, M.J. (1959) Dividends, Earnings, and Stock Prices. The Review of Economics and Statistics, 41, 99-105. http://dx.doi.org/10.2307/1927792

[13] Gordon, M.J. (1963) Optimal Investment and Financing Policy. The Journal of Finance, 18, $264-272$.

[14] Lintner, J. (1962) Dividends, Earnings, Leverage, Stock Prices and the Supply of Capital to Corporations. The Review of Economics and Statistics, 44, 243-269. http://dx.doi.org/10.2307/1927792

[15] Azhagaiah, R. and Priya, N.S. (2008) The Impact of Dividend Policy on Shareholders' Wealth. International Research Journal of Finance and Economics, 20, 180-187.

[16] Khan, S.H. (2009) Determinants of Share Price Movements in Bangladesh. Unpublished Master Thesis, Blekinge Institute of Technology, Sweden.

[17] Kumar, S. and Mohan, M. (1975) Determinants of Share Prices in India. The Indian Economic Journal, 23, 23-27.

[18] Nishat, M. (1995) Share Prices, Dividend \& Share Retained Earnings Behaviour in Pakistan Stock Market. The Indian Economic Journal, 40, 56-95.

[19] Gujarati, D.N. and Sangeetha (2007) Basic Econometrics. Tata McGraw-Hill, New Dehli.

[20] Nirmala, P.S., Sanju, P.S. and Ramachandran, M. (2011) Determinants of Share Prices in India. Journal of Emerging Trends in Economics and Management Sciences, 2, 124-130. 
Scientific Research Publishing (SCIRP) is one of the largest Open Access journal publishers. It is currently publishing more than 200 open access, online, peer-reviewed journals covering a wide range of academic disciplines. SCIRP serves the worldwide academic communities and contributes to the progress and application of science with its publication.

Other selected journals from SCIRP are listed as below. Submit your manuscript to us via either submit@scirp.org or Online Submission Portal.
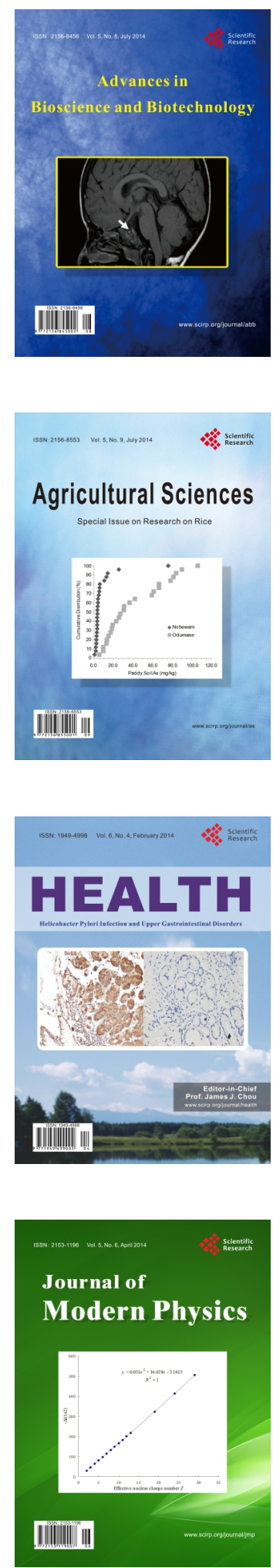
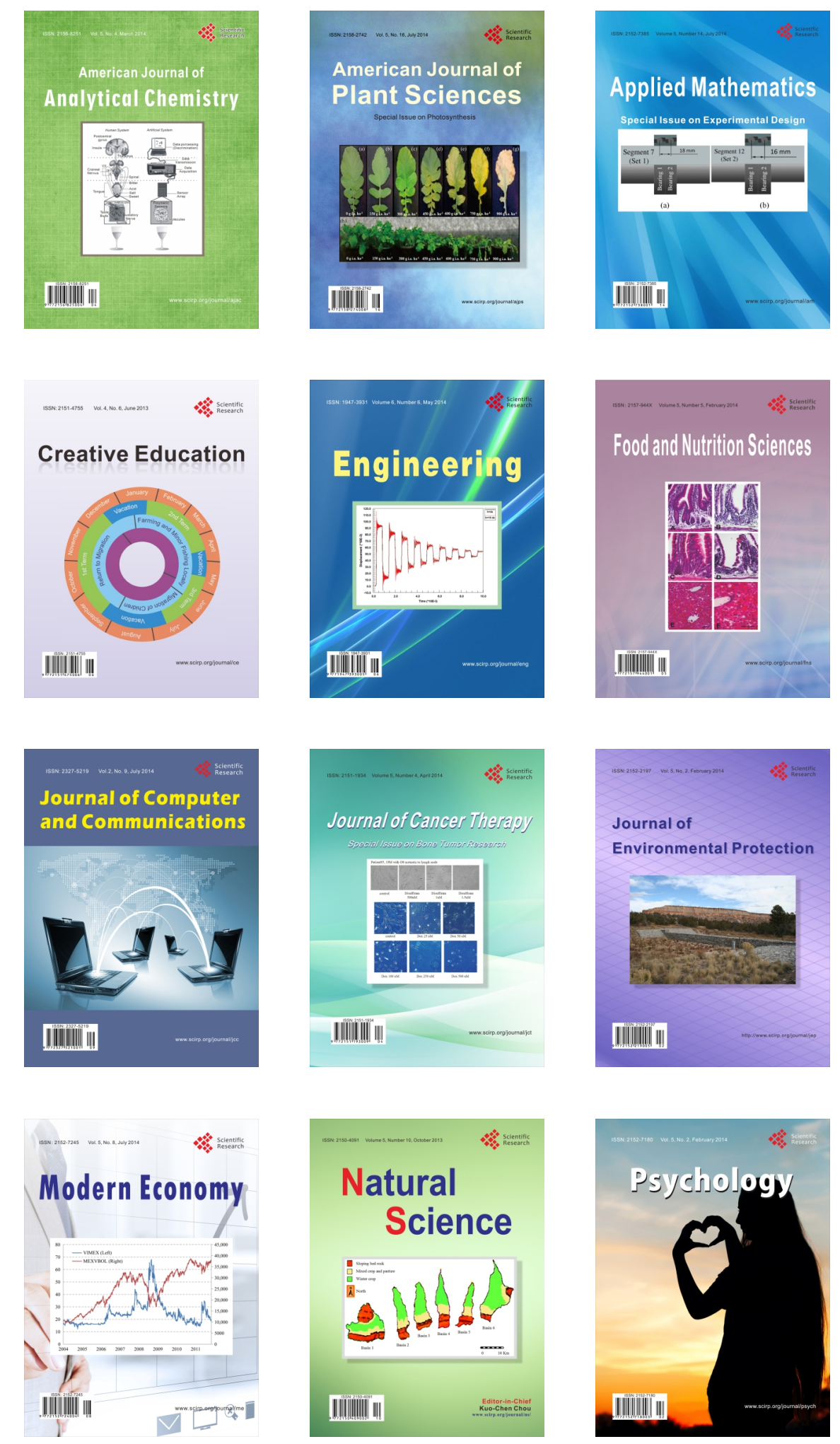